Jurnal Penelitian Farmasi Indonesia 10(1), Juni 2021

ISSN : 2302-187X e-ISSN 2656-3614

\title{
POTENSI UBI JALAR PUTIH (Ipomoea batatas linneaus varietas) SEBAGAI MEDIA ALTERNATIF PERTUMBUHAN BAKTERI Staphylococcus aureus
}

\author{
Wahyu Ramadhan ${ }^{1}$,Siti Juariah ${ }^{1 *}$, Vica Octa Ryani ${ }^{1}$ \\ ${ }^{1}$ Universitas Abdurrab; Jl. Riau Ujung, No 73 Pekanbaru Riau \\ e-mail: $\underline{\text { sitijuariah@univrab.ac.id }}$
}

\begin{abstract}
ABSTRAK
Pertumbuhan bakteri sangat tergantung kepada sumber nutrisi, sumber energi dan kondisi lingkungannya. Nutrien agar (NA) adalah media yang sering digunakan untuk pertumbuhan bakteri. Penggunaan nutrien agar membutuhkan biaya yang besar sehingga dianggap tidak mempunyai nilai ekonomis. Penggunaan media alternatif yang murah, mudah didapat, dan memiliki sumber nutrisi yang besar untuk pertumbuhan bakteri sangan dibutuhkan. Ubi jalar putih (Ipomoea batatas linneaus varietas) memiliki kandungan karbohidrat yang tinggi sehingga dapat di manfaatkan sebagai sumber karbon untuk pertumbuhan bakteri. Tujuan dari penelitian ini adalah untuk mengevaluasi potensi dari ubi jalar putih (Ipomoea batatas linneaus varietas) sebagai media alternatif pertumbuhan bakteri Staphylococcus aureus. Penelitian ini menggunakan metode eksperimental laboratorium. Pertumbuhan bakteri Staphylococcus aureus diamati dan angka lempeng total (ALT) dihitung pada media nutrien agar (NA) dan media ubi jalar putih (Ipomoea batatas linneaus varietas). Berdasarkan hasil penelitian yang dilakukan, nutrien agar (NA) berukuran kecil dari $0,1 \mathrm{~cm}$ dengan warna kuning dan berbentuk bulat. Sedangkan pada ubi jalar putih (Ipomoea batatas linneaus varietas) mempunyai ukuran kecil dari $0,1 \mathrm{~cm}$ berwarna putih susu dengan bentuk bulat. Hasil perhitungan angka lempeng total (ALT) dari media nutrien agar (NA) adalah 1,6 X $\left(10^{4}\right)$ CFU sedangkan angka lempeng total (ALT) dari media ubi jalar putih (Ipomoea batatas linneaus varietas) adalah $8,9 \mathrm{X}\left(10^{4}\right) \mathrm{CFU}$. Dari hasil penelitian ini dapat disimpulkan bahwa ubi jalar putih (Ipomoea batatas linneaus varietas) berpotensi digunakan sebagai media alternatif pertumbuhan bakteri Staphylococcus aureus.
\end{abstract}

Kata kunci: Ubi jalar putih, Staphylococcus aureus, Angka lempeng total (ALT)

\begin{abstract}
Bacterial growth is highly dependent on nutrient sources, energy sources and environmental conditions. Nutrien agar is a medium that is often used for bacterial growth. The use of Nutrien agar requires a high cost, so it is considered to have no economic value. The use of alternative media is cheap, easy to obtain, and has a large source of nutrients for the growth of the required bacteria. White sweet potato (Ipomoea batatas linneaus variety) has a high carbohydrate content to be used as a carbon source for bacterial growth. The purpose of this study was to reveal the potential of white sweet potato (Ipomoea batatas linneaus variety) as an alternative medium for the growth of Staphylococcus aureus bacteria. This research uses experimental laboratory methods. Staphylococcus aureus growth was observed, and total plate number was calculated on nutrien agar and white sweet potato (Ipomoea batatas linneaus varieties) media. Based on the research results, Nutrien agar is small in size, from $0.1 \mathrm{~cm}$ to a yellow colour and round shape. In comparison, the white sweet potato (Ipomoea batatas linneaus variety) has a small size of $0.1 \mathrm{~cm}$, milky white with a round shape. The results of the calculation of the otal plate number from the Nutrien agar medium was $1.6 \mathrm{X}\left(10^{4}\right) \mathrm{CFU}$. In comparison, the total plate number from the white sweet potato (Ipomoea batatas linneaus variety) medium was $8.9 \mathrm{X}\left(10^{4}\right) \mathrm{CFU}$. From the results of this study, it can be concluded that white sweet potato (Ipomoea batatas linneaus variety) can be used as an alternative medium for the growth of Staphylococcus aureus bacteria.
\end{abstract}

Keywords : White sweet potato, Staphylococcus aureus, Total plate number

\section{PENDAHULUAN}

Bakteri Staphylococcus merupakan patogen bagi manusia dan mamalia lainnya. Staphylococcus dibagi menjadi dua kelompok berdasarkan kemampuan bakteri tersebut untuk membekukan plasma darah (reaksi koagulase). Staphylococcus dengan koagulase - positif merupakan spesies Staphylococcus aureus yang paling patogen. Staphylococcus aureus mengekspresikan berbagai protein ekstraseluler dan polisakarida, beberapa diantaranya berkorelasi dengan virulensi (Ekawati 2018). Bakteri membutuhkan media yang mengandung banyak sumber nutrisi agar tetap tumbuh dengan baik.

Karbohidrat sangat dibutuhkan oleh bakteri karena karbohidrat merupakan substrat utama untuk metabolisme bakteri. Hampir setengah berat kering suatu bakteri adalah unsur karbon. Karbon dapat ditemukan dalam senyawa karbohidrat sehingga karbohidrat sangat berperan penting untuk pertumbuhan bakteri. Bahan yang bisa digunakan untuk media pertumbuhan bakteri adalah bahan yang mampu menyediakan nutrisi untuk pertumbuhan bakteri (Radji 2009).

Ubi jalar putih mengandung nutrisi seperti: air $(65,24 \%)$, protein $(0,87 \%)$, lemak $(0,95 \%)$, abu $(0,93 \%)$, karbohidrat $(28,79 \%)$, serat $(65,24 \%)$, kalori 123 , kandungan karbohidrat ubi jalar putih lebih tinggi dibandingkan dengan ubi jalar kuning dan ubi jalar ungu, karbohidrat ubi jalar kuning hanya $(27,47 \%)$ sedangkan ubi jalar ungu hanya $(22,64 \%)$ (Koswara 2013). Penelitian yang telah dilakukan sebelumnya menemukan adanya kandungan karbohidrat yang berbeda pada umbi gadung dan umbi uwi sebagai media substitusi pertumbuhan bakteri Staphylococcus aureus dan Eschercia. coli. Media pertumbuhan bakteri dari umbi gadung merupakan media yang lebih baik karena banyaknya jumlah populasi bakteri yang tumbuh dibandingkan dengan umbi uwi (Wachidah 2016). 
Media biakan merupakan suatu bahan yang terdiri atas nutrisi yang digunakan untuk menumbuhkan mikroorganisme baik dalam mengkultur jamur, bakteri, dan mikroorganisme lain (Benson 2001). Nutrisi yang dibutuhkan mikroorganisme untuk pertumbuhannya meliputi karbon, nitrogen, unsur non logam seperti sulfur dan fosfor, unsur logam seperti calsium, zink, natrium, kalium, tembaga, mangan, magnesium, zat besi, vitamin, air, dan energi (Cappucino and Sherman 2013). Pada penelitian ini, potensi dari Ubi jalar putih (Ipomoea batatas linneaus varietas) dievaluasi sebagai media alternatif pertumbuhan bakteri Staphylococcus aureus.

\section{METODE PENELITIAN}

\subsection{Alat dan Bahan}

Alat yang digunakan dalam penelitian ini adalah kompor,pisau, tabung erlemeyer, tabung reaksi, cawan petri, sendok, spuit, autoklaf, oven, inkubator, api bunsen, timbangan analitik, ose. Bahan-bahan yang digunakan adalah ubi jalar putih (Ipomoea batatas linneaus varietas), media NA (Nutrien Agar), biakan Staphlococcus aureus, agar batang, aquades.

\subsection{Sterilisasi Alat}

Alat-alat yang digunakan untuk penelitian dicuci sampai bersih lalu dikeringkan, alat-alat dibungkus dengan aluminium foil, alat-alat lalu di sterilkan dalam oven pada suhu $170^{\circ} \mathrm{C}$ selama 1 jam, alat alat di keluarkan dari oven setelah cukup waktunya dan biarkan dingin (Soemarno 2000).

\subsection{Pembuatan Media NA (Nutrien agar)}

Media NA (Nutrien agar) ditimbang 5,6 gram, dilarutkan dalam akuades $200 \mathrm{~mL}$, diaduk hingga homogen dengan menggunakan batang pengaduk ditutup dengan kapas. Media NA dipanaskan hingga jernih. Setelah itu disetrilisasi dengan autoklaf pada suhu $121^{\circ} \mathrm{C}$ selama 15 menit. Media dituang ke dalam cawan petri secara aseptis, lalu dibiarkan dibiarkan di suhu ruangan hingga media memadat (Juariah and Sari 2018).

\subsection{Pembuatan Media Ubi Jalar Putih}

Sampel yang digunakan adalah ubi jalar putih (Ipomoea batatas linneaus varietas) yang terdapat di Pasar Tradisonal Loket Pekanbaru, Provinsi Riau, Indonesia. Media ubi jalar putih dilakukan dengan membuat ekstrak yang dilakukan dengan cara Ubi jalar $200 \mathrm{~g}, 300 \mathrm{~g}, 400 \mathrm{~g}$ direbus menggunakan $1000 \mathrm{~mL}$ akuades, lalu ditambahkan agar batang $20 \mathrm{~g}$ ke dalam air rebusan ubi jalar putih (Ipomoea batatas linneaus varietas). Selanjutnya di sterilkan dengan autoclave selama 15 menit suhu $121^{\circ} \mathrm{C}$ agar terbebas dari mikroba yang tidak diinginkan (Ariyanti and Rahayu 2016)

\subsection{Pembuatan Suspensi Bakteri}

Pembuatan suspensi bakteri dilakukan dengan cara mengambil sebanyak 1-2 ose biakan murni bakteri uji kemudian disuspensikan dalam larutan Nacl 0,9\% pada tabung reaksi steril dan homogenkan. Kekeruhan bakteri ditentukan hingga diperoleh kekeruhan sesuai dengan Mc Farland.

\subsection{Penanaman bakteri dengan metode Angka Lempeng Total (ALT)}

Sampel dibuat dalam beberapa variasi pengenceran $\left(1: 10\left(10^{1}\right), 1: 100\left(10^{2}\right), 1: 1000\left(10^{3}\right), 1\right.$ : $10.000\left(10^{4}\right)$ 1: $100.000\left(10^{5}\right)$, 1: $1000.000\left(10^{6}\right)$. Tabung Nacl 0,9\% yang telah disterilkan berisi $9 \mathrm{~mL}$ masing- masing tabung secara berurutan diberi tanda, $10^{1}, 10^{2}, 10^{3}, 10^{4}, 10^{5}$. Tabung yang ke 6 kontrol diisi Nacl $0,9 \%$ steril. disiapkan 6 petridis steril dan diberi tanda pada bagian belakang sesuai dengan kode pengenceran seperti pada tabung satu Petridis tanda kontrol. $1 \mathrm{~mL}$ koloni murni diambil lalu pindahkan kedalam tabung reaksi $10^{1}$ dan dihomogenkan. selanjunya dipindahkan ke petridis steril dengan kode pengenceran masing-masing.

\subsection{Perhitungan Koloni}

Perhitungan tiap-tiap Petridish dilakukan oleh 2 orang yang memiliki syarat visus mata normal untuk memperkecil kesalahan perhitungan, apabila jumlah koloni yang tumbuh pada Petridish kontrol lebih dari 10, pemeriksaan harus diulang karena sterilisasi dianggap kurang baik. Ideal jumlah koloni per pleat yang boleh dihitung yaitu antara 30 sampai dengan $300 \mathrm{CFU}$ (Colony From Unit)

\subsection{Analisis Data}

Penelitian ini dilakukan secara deskriptif. data yang diperoleh dari hasil perhitungan jumlah koloni disajikan dalam bentuk tabel dan gambar.

\section{HASIL DAN PEMBAHASAN}

Tabel 1. Pertumbuhan bakteri Staphylococcus Aureus Pada Media NA dan Ubi Jalar Putih (Ipomoea batatas linneaus varietas)

\begin{tabular}{lll}
$\begin{array}{c}\text { Karakteristik } \\
\text { Staphylococcus } \\
\text { aureus }\end{array}$ & Media NA & $\begin{array}{c}\text { Media } \\
\text { Alternatif Ubi } \\
\text { Jalar Putih }\end{array}$ \\
\hline Bentuk & Bulat & Bulat \\
Ukuran & Kecil $0,1 \mathrm{~cm}$ & Kecil 0,1 cm \\
Warna & Kuning & Putih Susu \\
Permukaan & Halus & Halus \\
Elevasi & Cembung & Cembung \\
\hline
\end{tabular}

Pada penelitian ini, hasil pengamtan dari media alternatif dari ubi jalar putih (Ipomoea batatas linneaus varietas) dan media NA pada pertumbuhan bakteri Staphylococcus aureus dapat dilihat pada tabel 1. 
Berdasarkan Tabel 1, Didapakan hasil pertumbuhan pada media NA adalah bentuk koloni bukat ukuran kecil 0,1 cm, warna kuning, permukaan halus dan elevasi cembung. Pertumbuhan pada media ubi jalar putih adalah bentuk bulat, ukuran $0,1 \mathrm{~cm}$, warna putih susu, permukaan halus, dan elevasi cembung.

Tabel 2. Perhitungan Koloni Angka Lempeng Total (ALT) Pada Media NA dan Ubi Jalar Putih (Ipomoea batatas linneaus varietas)

\begin{tabular}{|c|c|c|c|c|c|c|}
\hline \multirow{2}{*}{ Perlakuan } & \multicolumn{5}{|c|}{ Pengenceran } & \multirow{2}{*}{ ALT } \\
\hline & $10^{1}$ & $10^{2}$ & $10^{3}$ & $10^{4}$ & $10^{5}$ & \\
\hline Perlakuan 1 & 133 & 130 & 90 & 76 & 67 & $1,5 \times 10^{6}$ \\
\hline Perlakuan 2 & 300 & 88 & 83 & 50 & 50 & $1,1 \times 10^{6}$ \\
\hline Perlakuan 3 & 70 & 53 & 50 & 30 & 24 & $8,9 \times 10^{4}$ \\
\hline Kontrol (+) & 300 & 69 & 38 & 24 & 0 & $1,5 \times 10^{3}$ \\
\hline Kontrol (-) & 0 & 0 & 0 & 0 & 0 & 0 \\
\hline
\end{tabular}

Keterangan

Kontrol (+) : Nutrien agar (NA)

Kontrol (-) : Ubi Jalar Putih

Perlakuan 1 : 200 Gram dalam $1000 \mathrm{ml}$ aquades

Perlakuan 2 : 300 Gram dalam $1000 \mathrm{ml}$ aquades

Perlakuan 3 : 400 Gram dalam $1000 \mathrm{ml}$ aquades

Berdasarkan hasil perhitungan koloni angka lempeng total pada tabel 2, dapat diamati hasil perhitungan koloni angka lempeng total pada NA adalah $1,5 \times 10^{3}$. Perhitungan koloni angka lempeng total pada ubi jalar putih (Ipomoea batatas linneaus varietas) pada perlakuan 1 adalah $\left(1,5 \times 10^{6}\right)$, perlakuan $2\left(1,1 \times 10^{6}\right)$ dan perlakuan $3\left(8,9 \times 10^{4}\right)$ secara bertuurut-turut.

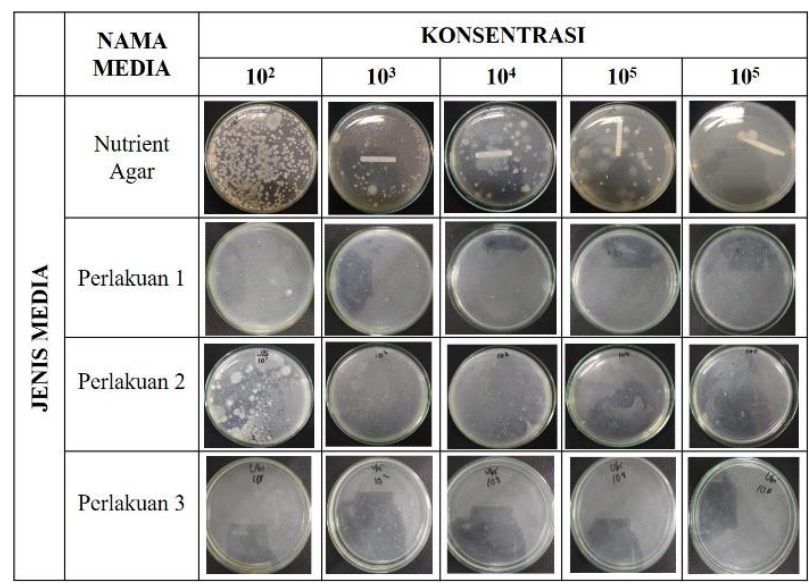

Gambar 1. Pertumbuhan bakteri Staphylococcus aureus pada Media Nutient Agar dan ubi jalar putih (Ipomoea batatas linneaus varietas)

Penelitian yang sudah dilakukan sebelumnya melaporkan bahwa kandungan nutrisi pada ubi jalar putih yaitu: air $(65,24 \%)$, protein $(0,87 \%)$, lemak $(0,95 \%)$, abu $(0,93 \%)$, karbohidrat $(28,79 \%)$, serat $(65,24 \%)$, kalori 123, kandungan karbohidrat ubi jalar putih lebih tinggi dibandingkan dengan ubi jalar kuning dan ubi jalar ungu, karbohidrat ubi jalar kuning hanya
$(27,47 \%)$ sedangkan ubi jalar ungu hanya $(22,64 \%)$ (Koswara 2013).

Angka lempeng total adalah angka yang menunjukkan jumlah bakteri dalam $1 \mathrm{~mL}$ atau 1 gram sampel (Agustiningrum 2018). dalam tes ini diketahui perkembangan banyaknya bakteri dalam sampel, dimana total bakteri di dalam media tempat tumbuhnya dan masing-masing bakteri yang dihasilkan akan berbentuk koloni yang tunggal. perhitungan angka lempeng total mikroorganisme dipilih dari cawan petri yang jumlah koloninya antara 30 -300. Hal ini dikarenakan media agar dengan jumlah koloni tinggi < 300 koloni tidak bisa dihitung secara statistik.

Media Nutrien agar (NA) sangat populer diugunakan untuk media tumbuh bakteri bakteri gram negatif maupun gram positif karena memiliki banyak sumber nutrisi bagi pertumbuhan bakteri. Media NA terbuat dari 3 gram ekstrak daging, 5 gram pepton, 1000 $\mathrm{mL}$ air dam 15 gram agar-agar (Irianto 2014). Pada media NA, koloni menghasilkan pigmen berwarna kuning dan koloni yang terbentuk terlihat lebih besar serta mudah diamati. Hal ini dikarenakan media NA merupakan media yang sudah teruji secara klinis baik untuk pertumbuhan bakteri.

Kandungan kompleks dalam media menyebabkan pertumbuhan mikroorganisme membutuhkan waktu yang lebih lama untuk menguraikan komponenkomponen sederhana yang dapat diserap sel dan digunakan untuk sintesis sel dan energi, dan perbedaan pertumbuhan bakteri dapat pula dipengaruhi oleh kandungan nutrisi, $\mathrm{pH}$, temperature, aerasi, konsentrasi garam dan kekuatan ionic medium (Jawetz et al. 2005).

Karbohidrat sangat dibutuhkan oleh bakteri sebagai sumber utama untuk metabolisme bakteri. Hampir setengah berat kering suatu bakteri adalah unsur karbon. Karbon dapat ditemukan dalam senyawa karbohidrat, protein dan lemak sehingga karbohidrat sangat berperan penting untuk pertumbuhan bakteri. Bahan yang bisa digunakan untuk media pertumbuhan bakteri adalah bahan yang mampu menyediakan nutrisi untuk pertumbuhan bakteri (Radji 2009).

Penelitian sebelumnya melaporkan bahwa media pertumbuhan bakteri dengan bahan umbi suweg, umbi talas dan umbi dan umbi kimpul menghasilkan jumlah koloni yang banyak akan tetapi ukuran koloninya seperti titik-titik (Purwati 2016). Media pertumbuhan bakteri dengan bahan umbi gayong, umbi garut, dan umbi gembili menghasilkan koloni bakteri yang besar dan hamper menyerupai koloni bakteri yang tumbuh pada media Nutrien agar. Hal ini dikarenakan bahwa umbi gayong, umbi garut, dan umbi gembili tidak mengandung lendir sama sekali sehingga pertumbuhannya sangat baik (Anisah 2015).

Berdasarkan hasil penelitian yang dilakukan, ubi jalar putih (Ipomoea batatas linneaus varietas) memiliki potensi untuk dimanfaatkan sebagai media pertumbuhan bakteri Stapyhlococcus aureus. 
Jurnal Penelitian Farmasi Indonesia 10(1), Juni 2021

ISSN : 2302-187X

e-ISSN 2656-3614

\section{SIMPULAN}

Berdasarkan hasil penelitian yang dilakukan, dapat disimpulkan bahwa pertumbuhan bakteri Staphylococcus aureus pada media ubi jalar putih (Ipomoea batatas linneaus varietas) berbentuk bulat, ukuran koloni bakteri sedang, pertumbuhan Stapyhlococcus aureus subur, kepadatan koloni yang terbentuk sangat padat, warna koloni putih susu, koloni terlihat jelas, mudah diamati, dan jumlah koloni banyak serta mudah untuk diamati. perhitungan koloni angka lempeng total pada ubi jalar putih (Ipomoea batatas linneaus varietas) pada perlakuan 1 adalah $\left(1,5 \times 10^{6}\right)$, perlakuan $2\left(1,1 \times 10^{6}\right)$ dan perlakuan $3\left(8,9 \times 10^{4}\right)$ secara bertuurut-turut. Penelitian ini membuktikan bahwa ubi jalar putih (Ipomoea batatas linneaus varietas) dapat digunakan sebagai media alternatif pertumbuhan bakteri Staphylococcus aureus.

\section{DAFTAR PUSTAKA}

Agustiningrum, Yuda. 2018. "Hubungan Hygiene Sanitasi dengan Angka Kuman Peralatan Makan Pada Pedagang Makanan Kaki Lima di Alun-Alun Kota Madiun." Stikes Bhakti Husada Mulia Madiun.

Anisah, Anisah. 2015. "Media Alternatif untuk Pertumbuhan Bakteri Menggunakan Sumber Karbohidrat yang Berbeda." Universitas Muhammadiyah Surakarta.

Ariyanti, Widya, and Triastuti Rahayu Rahayu. 2016. "Pertumbuhan Bakteri E. Coli dan Bacillus Subtilis pada Media Singkong, Ubi Jalar Putih, dan Ubi Jalar Kuning Sebagai Substitusi Media NA." UNIVERSITAS MUHAMMADIYAH SURAKARTA.

Benson, Harold J. 2001. M icrobiological A pplications. New York.

Cappucino, James G, and Natalie Sherman. 2013. "Manual laboratorium mikrobiologi." Jakarta: EGC.
Ekawati, Evi R. 2018. "Bakteriologi: Mikroorganisme Penyebab Infeksi." Deepublish, Yogyakarta.

Irianto, Koes. 2014. "Bakteriologi Mikologi dan Virologi; Panduan Medis dan Klinis."

Jawetz, Ernest, Joseph L Melnick, Edward A Adelberg, GF Brooks, JS Butel, and LN Ornston. 2005. "Mikrobiologi kedokteran." Jakarta: EGC.

Juariah, Siti, and Wulan Puspa Sari. 2018. "PEMANFAATAN LIMBAH CAIR INDUSTRI TAHU SEBAGAI MEDIA ALTERNATIF PERTUMBUHAN Bacillus sp." Klinikal Sains: Jurnal Analis Kesehatan 6 (1): 24-29.

Koswara, Sutrisno. 2013. "Teknologi Pengolahan Umbi-umbian: Ubi Jalar." UNIMED IPB: Bogor.

Purwati, Suci. 2016. "Pemanfaatan Sumber Karbohidrat Yang Berbeda (Umbi Suweg, Umbi Talas, Dan Umbi Kimpul) Sebagai Substitusi Media Na (Nutrient Agar) Untuk Pertumbuhan Bakteri." Universitas Muhammadiyah Surakarta.

Radji, Maksum. 2009. "Buku Ajar Mikrobiologi: Panduan Mahasiswa Farmasi \& Kedokteran."

Soemarno, S. 2000. "Isolasi dan Identifikasi Bakteri Klinik." Akademi Analisis Kesehatan. Jogjakarta. Hal 16: 103-105.

Wachidah, Istianah. 2016. "Pemanfaatan Umbi Gadung Dan Umbi Uwi Sebagai Media Alternatif Substitusi Nutrient Agar (Na) Untuk Pertumbuhan Bakteri." Universitas Muhammadiyah Surakarta. 